\title{
COMPARISON OF ARTIFICIAL DIETS FOR REARING Corcyra cephalonica (Stainton, 1865) (Lep., Pyralidae) for Trichogramma MASS PRODUCTION
}

\author{
BERNARDI, E. B., HADDAD, M. L. and PARRA, J. R. P. \\ Departamento de Entomologia, Fitopatologia e Zoologia Agrícola, ESALQ/USP, CEP 13418-900, \\ Piracicaba, SP, Brazil \\ Correspondence to: Elizabeth B. Bernardi, Departamento de Entomologia, Fitopatologia e Zoologia \\ Agrícola, ESALQ/USP, CEP 13418-900, Piracicaba, SP, Brazil, e-mail: jrpparra@carpa.ciagri.usp.br \\ Received January 5, 1999 - Accepted Juny 15, 1999 - Distributed February 28, 2000
}

(With 4 figures)

\begin{abstract}
The objective of this research was, based on biological studies, to determine and adequate diet for rearing Corcyra cephalonica (Stainton, 1865) in the laboratory so as to permit the rearing of this factitious host for Trichogramma mass production. The research was conducted at $25 \pm 1^{\circ} \mathrm{C}, \mathrm{RH} 60 \pm$ $10 \%$ and photophase of 14 hours. Six artificial diets were compared: a) whole wheat flour (48.5\%), ground rice (48.5\%) and sugar (3\%); b) ground rice (97\%) and sugar (3\%); c) whole wheat flour (48.5\%), rice flour (48.5\%) an sugar (3\%); d) whole wheat flour (97\%) and yeast (3\%); e) wheat germ (97\%) and yeast (3\%); f) rice bran (94\%), sugar (3\%) and yeast (3\%); f) rice bran (94\%), sugar (3\%) and yeast (3\%). All of the diets studied permitted the development of $C$. cephalonica although the diets with wheat germ and yeast and that consisting of rice bran, sugar and yeast proved to be the most adequate for rearing the moth. These diets reduced the total (egg-adult) cycle, shortened the egg laying period, and produced heavier adults. Studies on the fertility life tables showed that higher net reproduction rates (Ro) and finite ratio of increase $(\lambda)$ were obtained from adults reared on these diets.
\end{abstract}

Key words: Corcyra cephalonica, artificial diets, rearing, Trichogramma.

\section{RESUMO}

\section{Comparação de dieta artificial para criação de Corcyra Cephalonica (Stainton, 1865)} (Lep., Pyralidae) para a produção em massa de Trichogramma

O objetivo desta pesquisa foi, baseando-se em estudos biológicos, determinar uma dieta adequada para criação de Corcyra cephalonica (Stainton, 1865) em laboratório, que permitisse a criação deste hospedeiro alternativo para produção em massa de Trichogramma. A pesquisa foi conduzida a $25 \pm$ $1{ }^{\circ} \mathrm{C}$; UR $60 \pm 10 \%$ e fotofase de 14 horas. Seis dietas artificiais foram comparadas: a) farinha de trigo integral $(48,5 \%)$, arroz triturado $(48,5 \%)$ e açúcar (3\%); b) arroz triturado (97\%) e açúcar (3\%); c) farinha de trigo integral $(48,5 \%)$, farinha de arroz $(48,5 \%)$ e açúcar $(3 \%)$; d) farinha de trigo integral $(97 \%)$ e levedura de cerveja (3\%); e) germe de trigo (97\%) e levedura de cerveja (3\%); f) farelo de arroz (94\%), açúcar (3\%) e levedura de cerveja (3\%). Todas as dietas estudadas permitiram o desenvolvimento de $C$. cephalonica, embora as dietas à base de germe de trigo e levedura de cerveja e aquela composta de farelo de arroz, açúcar e levedura de cerveja tenham sido as mais adequadas para a criação da traça. Essas dietas reduziram o ciclo total (ovo-adulto), concentraram o período de postura e produziram adultos mais pesados. Nesses meios foram obtidos, por meio do estudo de tabelas de vida de fertilidade, maiores taxas líquidas de reprodução $(\mathrm{Ro})$ e razão finita de aumento $(\lambda)$.

Palavras-chave: Corcyra cephalonica, dietas artificiais, criação, Trichogramma. 


\section{INTRODUCTION}

Along with Anagasta kuehniella (Zeller, 1879) and Sitotroga cerealella (Olivier, 1819), the moth Corcyra cephalonica (Stainton, 1865) is one of the most used factitious hosts for Trichogramma production in several countries of the world (Parra, 1997).

There is a worldwide controversy as to the choice of these different hosts and A. kuehniella is used in some countries of Europe and in Canada, mainly after Lewis et al. (1976) published the study showing its superiority over the Angoumois grain moth; however, in other countries such as Russia, Germany, USA, Cuba, Colombia, Peru, etc. preference is given to $S$. cerealella, mainly because this factitious host is easily reared (Hassan, 1997).

In some parts of Brazil $S$. cerealella is used for Trichogramma pretiosum, Riley, 1879 production, while the Department of Entomology Plant Pathology and Agricultural Zoology, at ESALQ, that has maintained a pest control program via Trichogramma since the eighties, has used $A$. kuehniella to achieve the development of more vigorous parasitoids (Parra et al., 1991).

Recently Gomes (1997) showed that $A$. kuehniella is actually the most adequate among those studied for T. pretiosum and that $C$. cephalonica should be used for the species $T$. galloi Zucchi, 1998; this author also reported that $S$. cerealella is the least adequate moth for these two species of Trichogramma.

The technology for A. kuehniella egg production is available (Parra, 1997) whereas studies in this direction for C. cephalonica are still scarce, even though Chinese researchers have long been using this species along with silkworm eggs for the production of this parasitoid.

Therefore, in order to develop a methodology for mass rearing of C. cephalonica for Trichogramma production, artificial diets were compared based on biological studies and on fertility life tables to determine the most adequate for rearing this species in the laboratory.

\section{MATERIAL AND METHODS}

The insects originated from a stock rearing in the Insect Biology laboratory of the Department of Entomology, Plant Pathology and Agricultural
Zoology, ESALQ/USP. The research was conducted at $25 \pm 1{ }^{\circ} \mathrm{C}$, RH $60 \pm 10 \%$, and photophase of $14 \mathrm{~h}$. The biological development of C. cephalonica on 6 diets (Table 1) was studied.

The experimental design was entirely randomized, with five replications, each plot consisting of 100 eggs placed over diets maintained in cylindrical plastic boxes of $11 \mathrm{~cm}$ diameter and $8 \mathrm{~cm}$ height with an opening on top, covered by a thin cloth for ventilation. The following parameters were observed in each treatment: duration of the eggadult period, viability of the period, and weight of newly emerged adults.

Fifteen couples (emerged on the same day) were analyzed per treatment and the separation by sex was based on the labial palpi (Ayyar, 1934) (Fig. 1). These couples were isolated in transparent glass tubes of $8.5 \mathrm{~cm}$ height and $2.5 \mathrm{~cm}$ diameter, closed by netting fastened by a rubber band allowing the passing of eggs.

The tubes were placed upside down on wire racks (glass container supporter) and supported by plastic syrup dosers placed at the base of the rack, where the eggs were collected. The following parameters were observed: number of eggs laid per female per day, total number of eggs/female, longevity of males and females, pre-oviposition period.

After emergence, on different diets, adults were killed under low temperatures and individually weighed ( 60 males and 60 females per treatment) on a precision balance.

The results found were submitted to variance analysis and the means were compared by Tukey test at a $5 \%$ probability.

Using the results obtained from the six diets studied, fertility life tables were prepared based on Silveira Neto et al. (1976), and Ro, T, rm, and $\lambda$ were calculated.

Using the comparative analysis of the development of C. cephalonica on the six diets selected (Operational Taxonomic Units - OTUs) involving biological parameters the Cluster Analysis was performed (Sneath \& Sokal, 1973) where the characters (biological parameters) were transformed into tertiary vectors. Thus, considering the mean values (CI) (confidence interval) of a specific parameter $(\mathrm{P})$ for the 6 diets we have

$$
1 \rightarrow \mathrm{P}<\mathrm{CI} ; 2 \rightarrow \mathrm{P}=\mathrm{CI} \text { and } 3 \rightarrow \mathrm{P}>\mathrm{CI}
$$




\section{TABLE 1}

Composition of diets used to evaluate the biological development of $C$. cephalonica.

\begin{tabular}{|c|l|r|}
\hline Diets & \multicolumn{1}{|c|}{ Composition } & Components proportion (\%) \\
\hline \multirow{3}{*}{ A } & whole wheat flour & 48.5 \\
& ground rice & 48.5 \\
& sugar & 3.0 \\
\hline \multirow{2}{*}{ B } & ground rice & 97.0 \\
& sugar & 3.0 \\
\hline \multirow{3}{*}{ C } & whole wheat flour & 48.5 \\
& ground rice & 48.5 \\
& sugar & 3.0 \\
\hline \multirow{2}{*}{ D } & whole wheat flour & 97.0 \\
& yeast & 3.0 \\
\hline \multirow{2}{*}{ E } & wheat germ & 97.0 \\
& yeast & 3.0 \\
\hline \multirow{2}{*}{ F } & rice bran & 94.0 \\
& sugar & 3.0 \\
& yeast & 3.0 \\
\hline
\end{tabular}

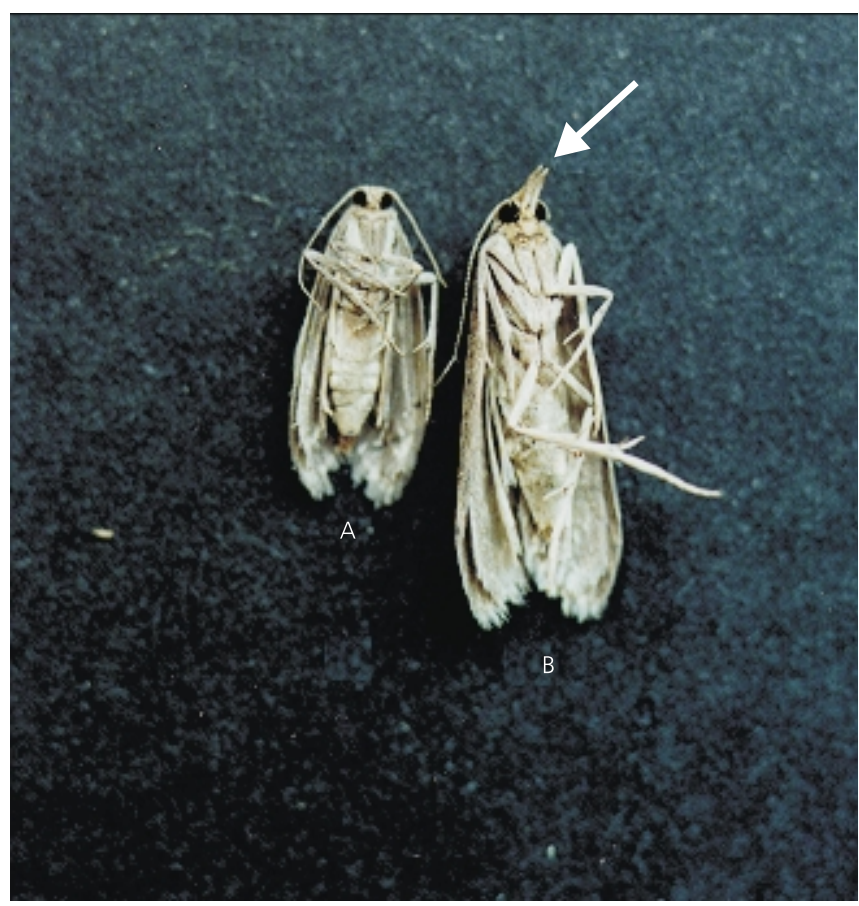

Fig. 1 - Labial palpi of C. cephalonica. A, short and blunt (\%); B, long and pointed (\&). 
The biological parameters used in this analysis were duration of the period (egg-adult); total viability; total number of eggs/female; longevity ( $\%$ and $\&$ ); average weight of adults; mean number of laid eggs.

\section{RESULTS AND DISCUSSION}

\section{Comparison of diets for Corcyra cephalonica (Stainton, 1865)}

With regard to the duration of the egg-adult period, diets $\mathrm{E}$ (wheat germ and yeast) and $\mathrm{F}$ (rice bran, sugar and yeast) proved to be the most adequate for the insect, as they provided a reduction in that period, although they did not statistically differ from diets B (ground rice and sugar) and $\mathrm{D}$ (whole wheat flour and yeast). Based on Singh (1983), who recommended $75 \%$ of total viability as the minimum percentage for an artificial diet to be considered adequate for insect rearing, the diets under study are close to that value, specially diets $\mathrm{B}$ and $\mathrm{E}$. The total viability results (Table 2) observed in this study are within the range reported by Cox et al. (1981), Osman (1986), and Shazali \& Smith (1986), even though they differ from those reported by Russell et al. (1980) and Cadapan (1988). In statistical terms, the mortality in the egg-adult period was similar on the 6 diets studied.

TABLE 2

Duration of the egg-adult period and total viability of $C$. cephalonica reared on 6 diets. Temperature: $25 \pm 1^{\circ} \mathrm{C}$; RH: $60 \pm 10 \%$; photophase: $14 \mathrm{~h}$.

\begin{tabular}{|l|c|c|c|}
\hline \multirow{2}{*}{ Diets } & \multicolumn{2}{|c|}{ Duration (days) } & \multirow{2}{*}{$\begin{array}{c}\text { Total } \\
\text { viability* }\end{array}$} \\
\cline { 2 - 3 } & Means* & Interval & $66.2 \mathrm{a}$ \\
\hline $\mathrm{A}(\mathrm{WWF} / \mathrm{GR} / \mathrm{S})$ & $92.69 \pm 13.28 \mathrm{a}$ & $(57-163)$ & $80.4 \mathrm{a}$ \\
$\mathrm{B}(\mathrm{GR} / \mathrm{S})$ & $70.16 \pm 5.34 \mathrm{bc}$ & $(46-158)$ & $63.2 \mathrm{a}$ \\
$\mathrm{C}(\mathrm{WWF} / \mathrm{RF} / \mathrm{S})$ & $85.35 \pm 76.82 \mathrm{ab}$ & $(52-167)$ & $73.0 \mathrm{a}$ \\
$\mathrm{D}(\mathrm{WWF} / \mathrm{Y})$ & $76.31 \pm 6.14 \mathrm{abc}$ & $(57-131)$ & $84.6 \mathrm{a}$ \\
$\mathrm{E}(\mathrm{WG} / \mathrm{Y})$ & $62.70 \pm 10.29 \mathrm{c}$ & $(43-147)$ & $71.2 \mathrm{a}$ \\
$\mathrm{F}(\mathrm{RB} / \mathrm{S} / \mathrm{Y})$ & $63.41 \pm 8.25 \mathrm{c}$ & $(46-104)$ & \\
\hline
\end{tabular}

* Means followed by same letters do not differ by Tukey's test at $5 \%$ probability.

The differences reported may be due to environmental conditions (temperature and humidity), physical form of the food used (whole grain, ground grain or bran), different strains of the insect or due to the methodology used itself.

The number of eggs laid per female varied greatly in all diets resulting in no statistical differences in relation to this parameter on the 6 media analyzed. However, diets $\mathrm{A}$ and $\mathrm{C}$ remained below the mean of these values (Fig. 2). There was a high egg concentration on diets $\mathrm{B}, \mathrm{E}$, and $\mathrm{F}$ in the first days of life of females; diets $\mathrm{E}$ and $\mathrm{F}$ presented a shorter egg laying period, a desirable fact in mass rearing (Fig. 3), provided there is no reduction in the total number of eggs laid per female; this characteristic was also presented by insects deriving from diet $\mathrm{B}$. Few females deriving from diets $\mathrm{B}, \mathrm{E}$, and $\mathrm{F}$ failed to egg lay on the first days of life, unlike the females reared on diets A, C, and D (Fig. 3).
Females were heavier than males on all diets studied. Females resulting from diets $\mathrm{E}$ and $\mathrm{F}$ were the heaviest; on diet $\mathrm{F}$ females were 1.9 times heavier than males (Table 3). Even though there is a direct correlation between weight of female adults and fertility for several Lepidoptera (Norris, 1934, cited by Russell et al., 1980), in this study probably all of the diets provided the development of females up to a minimum size which did not impair egg laying, since there was no difference in the egg laying capacity relating to different diets, even though weight variations occurred (Table 3 ).

Considerable variation occurred in the weight of males resulting from the six diets (Table 3). Diets $\mathrm{E}$ and $\mathrm{F}$ produced heavier males also (Table 3); the values achieved are similar to those found by Cox et al. (1981), who found values of 12.9 and $24.6 \mathrm{mg}$ for males and females, respectively, and Mbata (1989), who reported $12.7 \mathrm{mg}$ for males and 22.4 for females. 


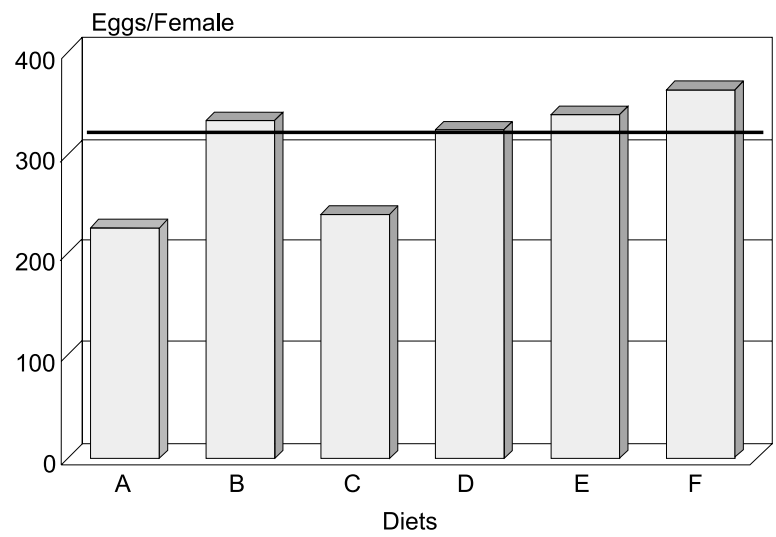

Fig. 2 - Total number of eggs per $C$. cephalonica female reared on 6 different diets. The dark bar represents the mean $(\overline{\mathrm{x}}=304.21)$. Temp.: $25 \pm 1^{\circ} \mathrm{C}$; RH: $60 \pm 10 \%$; Photophase: $14 \mathrm{~h}$.

TABLE 3

Weight of $C$. cephalonica adults reared on 6 diets. Temp.: $25 \pm 1^{\circ} \mathrm{C}$; UR: $60 \pm 10 \%$; photophase: 14 h.

\begin{tabular}{|l|c|c|}
\hline \multirow{2}{*}{\multicolumn{1}{c|}{ Diets }} & \multicolumn{2}{|c|}{ Weight of adults (mg) } \\
\cline { 2 - 3 } & Male & Female \\
\hline $\mathrm{A}(\mathrm{WWF} / \mathrm{GR} / \mathrm{S})$ & $15.07 \pm 1.10 \mathrm{~b}$ & $27.12 \pm 3.47 \mathrm{~b}$ \\
$\mathrm{~B}(\mathrm{GR} / \mathrm{S})$ & $12.22 \pm 1.53 \mathrm{c}$ & $21.38 \pm 3.00 \mathrm{c}$ \\
$\mathrm{C}(\mathrm{WWF} / \mathrm{RF} / \mathrm{S})$ & $14.81 \pm 1.26 \mathrm{~b}$ & $25.71 \pm 2.88 \mathrm{~b}$ \\
$\mathrm{D}(\mathrm{WWF} / \mathrm{Y})$ & $14.76 \pm 1.11 \mathrm{~b}$ & $28.17 \pm 3.26 \mathrm{~b}$ \\
$\mathrm{E}(\mathrm{WG} / \mathrm{Y})$ & $15.98 \pm 1.26 \mathrm{ab}$ & $33.73 \pm 3.50 \mathrm{a}$ \\
$\mathrm{F}(\mathrm{RB} / \mathrm{S} / \mathrm{Y})$ & $17.33 \pm 1.64 \mathrm{a}$ & $32.39 \pm 2.39 \mathrm{a}$ \\
\hline
\end{tabular}

The lowest values for both sexes were found on diet B (ground rice and sugar) (Table 3).

Both sexes were equally affected, since the sexual ratio was close to $0.5(1 \%: 1 \&)$ on the 6 diets studied. These values were close to those found by Kamel \& Hassanein (1967) and Cox et al. (1981) and Etman et al. (1988), who obtained a sexual ratio close to $1: 1$.

Adult malformation (specially on wings) was quite low on all of the diets (never higher than $1.64 \%$ ), which indicates that these malformations were not due to inadequate nutrition. Diets $\mathrm{E}$ and $F$ practically did not cause malformations.

Adult longevity, pre-oviposition and incubation period were not affected by the different diets; on all diets C. cephalonica males lived longer than females.

Microorganism contamination was also negligible in all treatments; only the occurrence of fungus (probably Aspergillus sp.) was recorded in one plot of treatment A.

\section{Fertility life table and Cluster Analysis}

The mean duration of a generation ( $\mathrm{T})$, that is, the period of time elapsed between birth of parents and that of their offspring, was shorter on diets $E$ ( 65.5 days) and $F$ (67.5 days) (Table 2). On the remaining diets longer periods were observed, where 98.2 days were recorded on diet A.

The population increase capacity of the species at each generation, estimated by the net reproduction rate (Ro), was higher on diets $\mathrm{E}$ and F. Comparing the other diets it was shown that diets $\mathrm{A}$ and $\mathrm{C}$ provided the lowest net reproduction rates. The data demonstrated that after one generation the population increased 73.58, 129.93, 78.41, 124.50, 154.51, and 130.59 times on diets A, B, C, D, E, and F, respectively.

The finite ratio of increase $(\lambda)$, which represents the number of individual(s) added to the population per female and which will produce female(s) was higher on diets $\mathrm{E}$ and $\mathrm{F}$, as compared to the remaining diets studied (Table 4). 

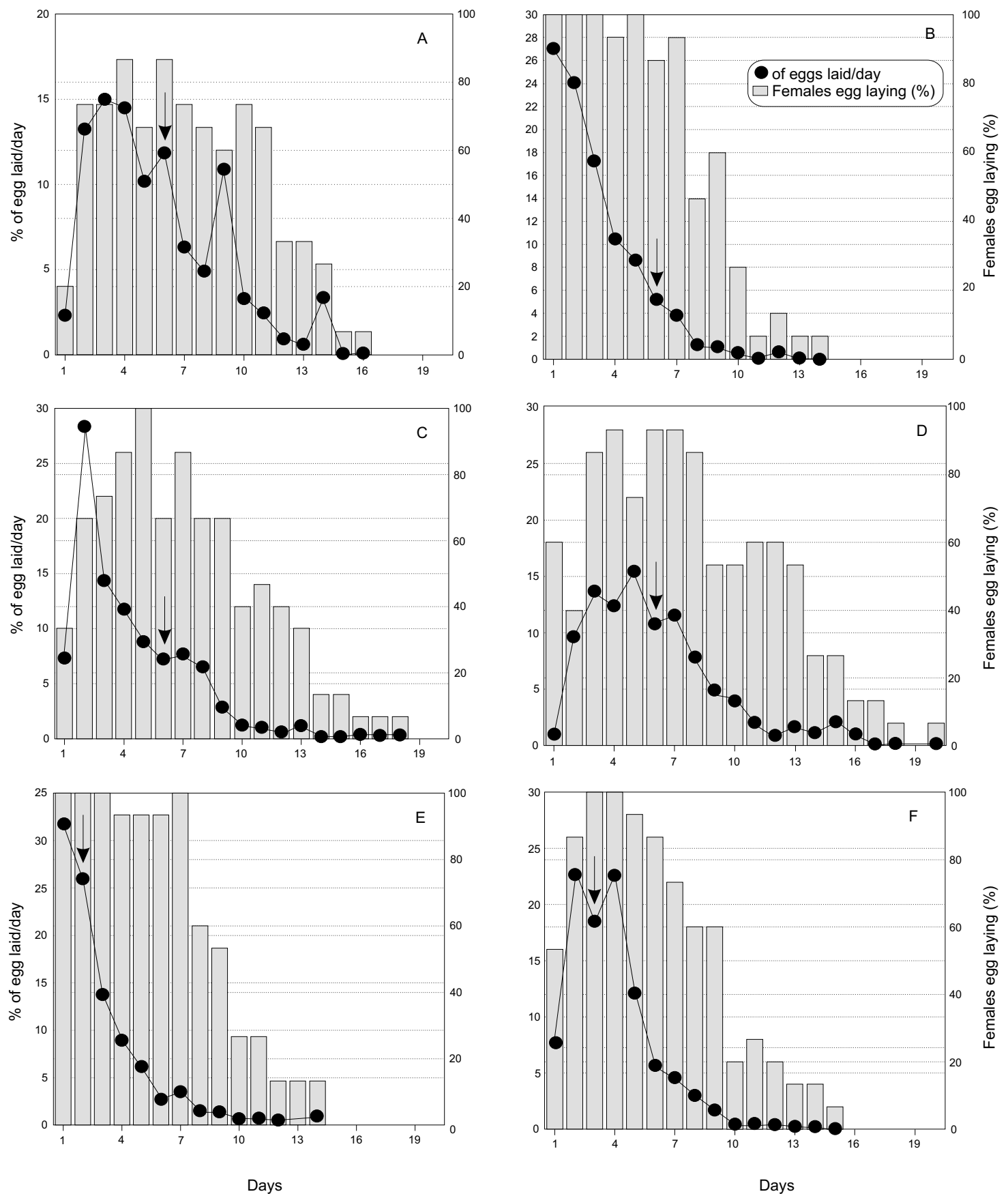

Fig. 3 - Daily rhythm of $C$. cephalonica egg laying and $\%$ of \& that laid eggs during life span on different diets. The arrow indicates $70 \%$ of eggs laid. Temp.: $25 \pm 1^{\circ} \mathrm{C}$; RH: $60 \pm 10 \%$; Photophase: $14 \mathrm{~h}$.

The cluster analysis, grouping the different parameters studied, led to the conclusion that diets $\mathrm{E}$ (wheat germ and yeast) and F (rice bran, sugar, and yeast) are similar at 0.625 (Fig. 4). These diets presented a shorter duration of the total cycle, high total viability and heavier adults than those originating from the other means studied. 


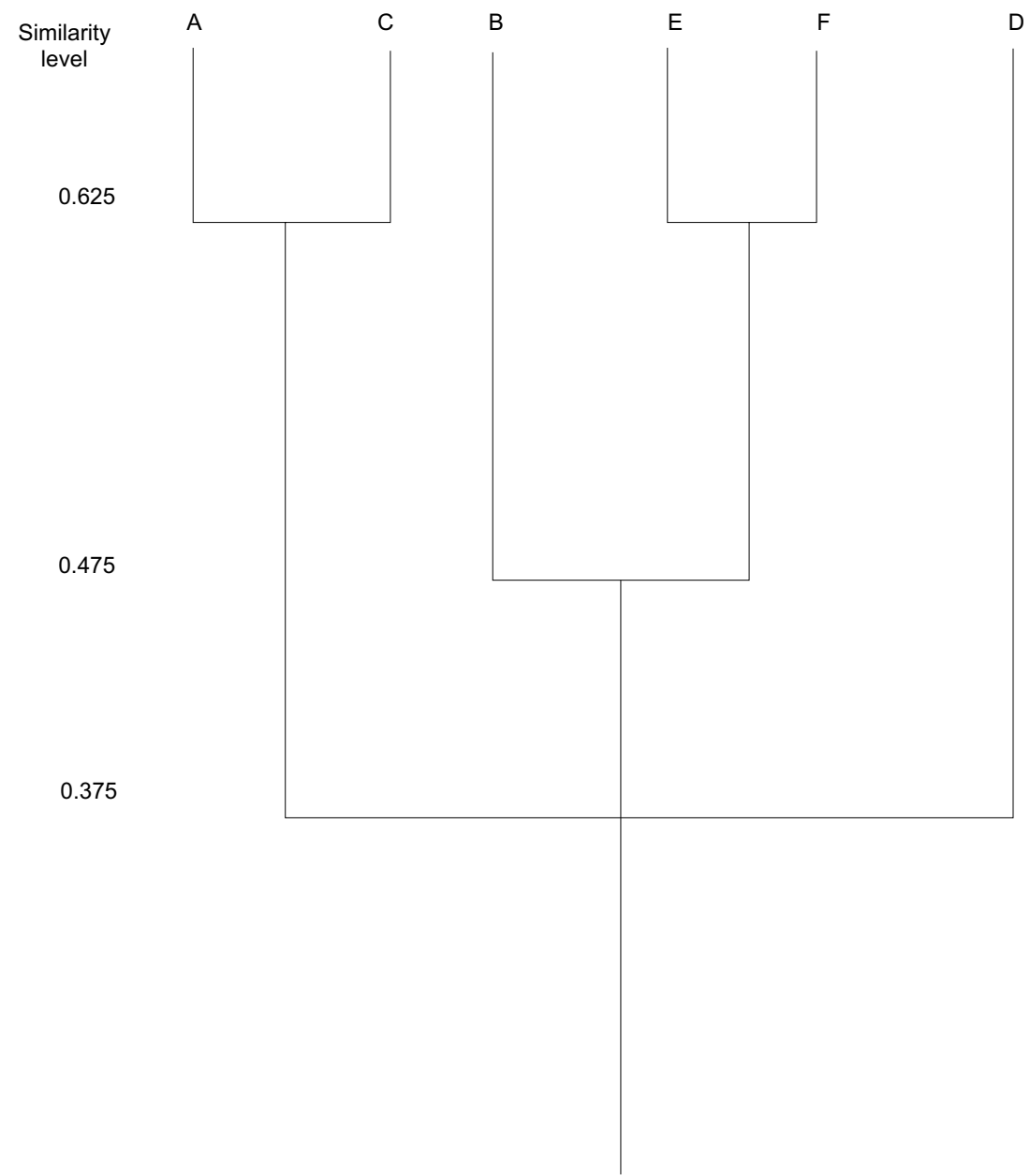

Fig. 4 - Phenogram obtained from the cluster analysis for the 6 diets tested for rearing C. cephalonica.

TABLE 4

Fertility life table of $C$. cephalonica reared on 6 diets. Temperature: $25 \pm 1^{\circ} \mathrm{C}$; RH: $60 \pm 10 \%$; photophase: $14 \mathrm{~h}$.

\begin{tabular}{|l|c|c|c|c|}
\hline \multicolumn{1}{|c|}{ Diets } & Ro & T(days) & rm & $\lambda$ \\
\hline $\mathrm{A}(\mathrm{WWF} / \mathrm{GR} / \mathrm{S})$ & 73.58 & 98.2 & 0.04377 & 1.0447 \\
$\mathrm{~B}(\mathrm{GR} / \mathrm{S})$ & 129.93 & 73.6 & 0.06616 & 1.0684 \\
$\mathrm{C}(\mathrm{WWF} / \mathrm{RF} / \mathrm{S})$ & 78.41 & 90.4 & 0.04825 & 1.0494 \\
$\mathrm{D}(\mathrm{WWF} / \mathrm{Y})$ & 124.50 & 82.9 & 0.05819 & 1.0599 \\
$\mathrm{E}(\mathrm{WG} / \mathrm{Y})$ & 154.51 & 65.6 & 0.07683 & 1.0799 \\
$\mathrm{~F}(\mathrm{RB} / \mathrm{S} / \mathrm{Y})$ & 130.59 & 67.5 & 0.07218 & 1.0748 \\
\hline
\end{tabular}

Emergence of individuals originated from diets $\mathrm{E}$ and $\mathrm{F}$ was more uniform, and the egg laying rate was concentrated on the first days of the female's life. The finite ratio of increase $(\lambda)$ was high in both food substrates. Although diet B (ground rice and sugar) is a quite simple diet (Table 1), it was adequate for rearing $C$. cephalonica since it was similar to diets $\mathrm{E}$ and $\mathrm{F}$ at the 0.475 level of 
similarity. The only restriction to this diet is the low weight of adults obtained (specially females) which were $37 \%$ and $34 \%$ lighter in weight than those reared on diets $\mathrm{E}$ and $\mathrm{F}$, respectively (Table 3 ). Although the number of eggs laid by females reared on this diet was similar to that obtained from the remaining diets (Fig. 2), there may be a decrease in the laying capacity along generations on this medium B, since the study covered only one laboratory generation.

\section{REFERENCES}

AYYAR, P. N. K., 1934, A very destructive pest of stored products in South India, Corcyra cephalonica, Staint (Lep.). Bulletin of Entomological Research, London, 25: 155-69.

CADAPAN, E. P., 1988, Trichogramma mass production in the Phillippines. In: International Symposium Trichogramma and Other Egg Parasites, 2., Guangzhou, 1986. Paris, INRA, pp. 305-9 (Les Colloques de l'INRA, 43).

COX, P. D., CRAWFORD, L. A., GJESTRUD, G., BELL, C. H. \& BOWLEY, C. R., 1981, The influence of temperature and humidity on the life-cycle of Corcyra cephalonica (Stainton) (Lepidoptera: Pyralidae). Bulletin of Entomological Research, London, 7: 171-81.

ETMAN, A. A. M., EL-SAYED, F. M. A., EESA, N. M. \& MOYRSY, L. E., 1988, Laboratory studies of the development, survival, mating behaviour and reproductive capacity of the rice moth, Corcyra cephalonica (Stainton) (Lep.: Galleridae). Journal of Applied Entomology, Hamburg, 106: 232-40.

GOMES, S. M., 1997, Comparação de três hospedeiros alternativos para criação e produção massal de Trichogramma pretiosum Riley, 1879 e T. galloi Zucchi, 1988. Dissertação de Mestrado, ESALQ/USP, Piracicaba, SP, 106p.

HASSAN, S. A., 1997, Criação da traça do milho, Sitotroga cerealella, para a produção massal de Trichogramma. In: J. R. P. Parra, \& R. A. Zucchi (eds.), Trichogramma e o Controle Biológico Aplicado, FEALQ, pp. 173-182.

KAMEL, A. H. \& HASSANEIN, M. H., 1967, Biological studies on Corcyra cephalonica Stainton. Bulletin de la Societé Entomologique d'Egypte, Cairo, 51: 17596.
LEWIS, W. I., NORDLUND, D. A., GROSS JR., H. R., PERKINS, W. D., KNIPLING, E. F. \& VOEGELÉ, J., 1976, Production and performance of Trichogramma reared on eggs of Heliothis zea and other hosts. Environmental Entomology, Lanham, 5(3): 449-57.

MBATA, G. N., 1989, Studies on some aspects of the biology of Corcyra cephalonica (Stainton) (Lepidoptera: Galleriidae). Journal of Stored Products Research, Oxford, 25(4): 181-6.

OSMAN, N., 1986, Development of the rice moth, Corcyra cephalonica (St.) on different grains. Pertanika, Selangor, 9(2): 155-9.

PARRA, J. R. P., 1997, Técnicas de criação de Anagasta kuehniella, hospedeiro alternativo para produção de Trichogramma. In: J. R. P. Parra \& R. A. Zucchi (eds.), Trichogramma e o Controle Biológico Aplicado, FEALQ, pp. 121-150.

PARRA, J. R. P., ZUCCHI, R. A., SILVEIRA NETO, S. \& HADDAD, M. L., 1991, Biology and thermal requirements of $T$. galloi and $T$. distinctum on two alternative hosts. In: International Symposium on Trichogramma and Other Egg Parasites, 3., San Antonio, 1990. Paris, INRA, pp. 81-4 (Les Colloques de l'INRA, 56).

RUSSELL, V. M., SCHULTEN, G. G. M. \& ROORDA, F. A., 1980, Laboratory observations on the development of the rice moth Corcyra cephalonica (Stainton) (Lepidoptera: Galleriinae) on millet and sorghum at $28^{\circ} \mathrm{C}$ and different relative humidities. Z. angew. Entomol., Hamburg, 89: 488-98.

SHAZALI, M. E. H. \& SMITH, R. H., 1986, Life history studies of externally feeding pests of stored sorghum: Corcyra cephalonica (Stainton) and Tribolium castaneum (Hbst.). Journal of Stored Products Research, Oxford, 22(2): 55-61.

SILVEIRA NETO, S., NAKANO, O., BARBIN, D. \& VILA NOVA, N. A., 1976, Manual de ecologia dos insetos. São Paulo, Agronômica Ceres, 419p.

SINGH, P., 1983, A general purpose laboratory diet mixture for rearing insects. Insect Science and its Application, Elmsford, 4(4): 357-62.

SNEATH, P. H. A. \& SOKAL, R. R., 1973, Numerical taxonomy. San Francisco, W. H. Freeman, 573p. 